Contr. Mineral. and Petrol. 30, 72-83 (1971)

(C) by Springer-Verlag 1971

\title{
Stability of Pyrope-Quartz in the System $\mathrm{MgO}-\mathrm{Al}_{2} \mathrm{O}_{3}-\mathrm{SiO}_{2}$
}

\author{
B. J. Hensen and E. J. Essene* \\ Department of Geophysics and Geochemistry, Australian National University
}

Received October 1, 1970

Abstract. Pyrope and quartz are stable with respect to aluminous enstatite and sillimanite
at $1400^{\circ} \mathrm{C}, 20 \mathrm{~kb}$ and at $1100{ }^{\circ} \mathrm{C}, 16 \mathrm{~kb}$. The phase boundary limiting the coexistence of
pyrope and quartz towards lower pressures is probably slightly curved. A slope of $15 \mathrm{bars} /{ }^{\circ} \mathrm{C}$
at $1400^{\circ}$ and of $10 \mathrm{bars} /{ }^{\circ} \mathrm{C}$ at $1000^{\circ} \mathrm{C}$ has been estimated from the experimental data.
Between 1050 and $1100{ }^{\circ} \mathrm{C}$ the curve is intersected by the kyanite-sillimanite phase boundary.
The calculated slope of the reaction aluminous enstatite + kyanite $\rightleftharpoons$ pyrope + quartz is
negative (ca. $18-25$ bars $/{ }^{\circ} \mathrm{C}$. The existence of a negative slope has been demonstrated experi-
mentally. Experimental evidence indicates that the assemblage aluminous enstatite and
sillimanite is metastable with respect to sapphirine + quartz at high temperature. The
invariant point involving the phases pyrope-sapphirine-aluminous enstatite-sillimanite-quartz
is estimated to occur at $1125^{\circ} \pm 25^{\circ} \mathrm{C}$ and $16 \pm 1 \mathrm{~kb}$. A model phase diagram for the silica-
saturated part of the system $\mathrm{MgO}-\mathrm{Al}_{2} \mathrm{O}_{3}-\mathrm{SiO} \mathrm{O}_{2}$ has been constructed. The position of three
invariant points in this system has been estimated on the basis of presently available data.

\section{Introduction}

A composition on the join pyrope-quartz in the system $\mathrm{MgO}-\mathrm{Al}_{2} \mathrm{O}_{3}-\mathrm{SiO}_{2}$ has been studied experimentally as part of a larger project investigating phase relations in the complex system $\mathrm{MgO}-\mathrm{FeO}-\mathrm{Al}_{2} \mathrm{O}_{3}-\mathrm{SiO}_{2}-\mathrm{CaO}-\mathrm{K}_{2} \mathrm{O}-\mathrm{Na}_{2} \mathrm{O}$ (Hensen and Green, 1970). Schreyer and Seifert $(1969 \mathrm{a}, \mathrm{b})$ have recently presented a comprehensive study of the system $\mathrm{MgO}-\mathrm{Al}_{2} \mathrm{O}_{3}-\mathrm{SiO}_{2}-\mathrm{H}_{2} \mathrm{O}$. This paper provides some additional experimental data and discusses their implications for the phase diagram of the high pressure-high temperature anhydrous part of the system.

The stability of pyrope under its own composition has been determined by Boyd and England (1959). They found that pyrope breaks down to aluminous enstatite, sapphirine and sillimanite over a temperature interval of $1100-1600^{\circ} \mathrm{C}$. Recent experimental evidence (Schreyer and Seifert, 1969a, b; Hensen and Green, 1969, 1970) suggests that most of this phase boundary where determined experimentally is metastable due to its intersection with the reaction: aluminous enstatite + sillimanite $\rightleftharpoons$ sapphirine + quartz. At temperatures above this intersection, pyrope will break down to aluminous enstatite, sapphirine and quartz. The reaction pyrope + quartz $\rightleftharpoons$ aluminous enstatite + sillimanite which has been determined experimentally in this study, in part in its metastable extension, also passes through the same invariant point.

\section{Experimental Procedure}

The experiments were carried out in a piston cylinder apparatus (0.5 inch diameter) with talc and boron-nitride as pressure media (Green and Ringwood, 1967). The "piston in"

* Present Address: Department of Geology, University of Michigan, Ann-Arbor, Michigan, U.S.A. 
method has been used and a $\mathbf{- 1 0 \%}$ pressure correction has been applied to the results. Temperatures have been controlled with Pt/Pt $-10 \%$ Rh thermocouples from $1100-1400^{\circ} \mathrm{C}$, and with chromel alumel at $1000^{\circ} \mathrm{C}$. No temperature corrections have been made. Probable maximum errors in temperature and pressure measurements are $\pm 10^{\circ} \mathrm{C}$ and $\pm 0.4 \mathrm{~kb}$.

\section{Chemical Composition and Starting Material}

The synthetic composition studied lies on the intersection of the joins enstatitecordierite and pyrope-quartz in the system $\mathrm{MgO}-\mathrm{Al}_{2} \mathrm{O}_{3}-\mathrm{SiO}_{2}$ (Fig. 1). Chemical composition is as follows:

$\mathrm{SiO}_{2} 54.26$ weight $\%=52.3 \mathrm{~mol} \%$

$\mathrm{Al}_{2} \mathrm{O}_{3} 20.92$ weight $\%=11.9 \mathrm{~mol} \%$

$\mathrm{MgO} 24.83$ weight $\%=35.7 \mathrm{~mol} \%$

The starting material used in the experiments consisted of:

(I) $50 \%$ finely ground oxide mix (fired at $1100{ }^{\circ} \mathrm{C}$ for 12 hours)

$25 \%$ pyrope and quartz synthesized at $1200^{\circ} \mathrm{C}, 27 \mathrm{~kb}$

$25 \%$ clino-enstatite + sillimanite (clino-enstatite from Tem Press INC).

Two runs at $1000{ }^{\circ} \mathrm{C}$ were made with a starting material consisting of:

(II) $80 \%$ clino-enstatite + sillimanite

$10 \%$ high pressure assemblage

and two other runs with

(III)

$72 \%$ clino-enstatite + sillimanite
$8 \%$ high pressure assemblage
$10 \%$ quartz
$10 \%$ kyanite

\section{Examination of the Sample}

Samples have been studied by optical and X-ray methods. In general, the changes in mineral assemblages observed were large and could be readily determined in this manner. The composition of aluminous enstatite has been determined by electron probe micro analyser.

\section{Results}

Experimental data and their interpretation are given in Table 1 and Fig. 1. With increasing pressure the assemblages cordierite-aluminous enstatite-quartz, aluminous enstatite-sillimanite-quartz and pyrope-quartz are found consecutively. At $1000^{\circ} \mathrm{C}, 15.3 \mathrm{~kb}$ pyrope has increased at the expense of enstatite and sillimanite, which are still present (note that in this run the starting material consisted of enstatite-sillimanite-pyrope-quartz only). However, at $14.4 \mathrm{~kb}$ at the same temperature the assemblage aluminous enstatite-kyanite-minor corundum was obtained from the same starting material in a longer run. This result indicates conditions in the stability field of kyanite. The kyanite-sillimanite phase boundary at $1000{ }^{\circ} \mathrm{C}$ is located at $14.67 \mathrm{~kb}$ according to the preferred curve of Richardson et al. (1969). Taking experimental uncertainties into account there is no disagreement between these data. This result suggested that the growth of 


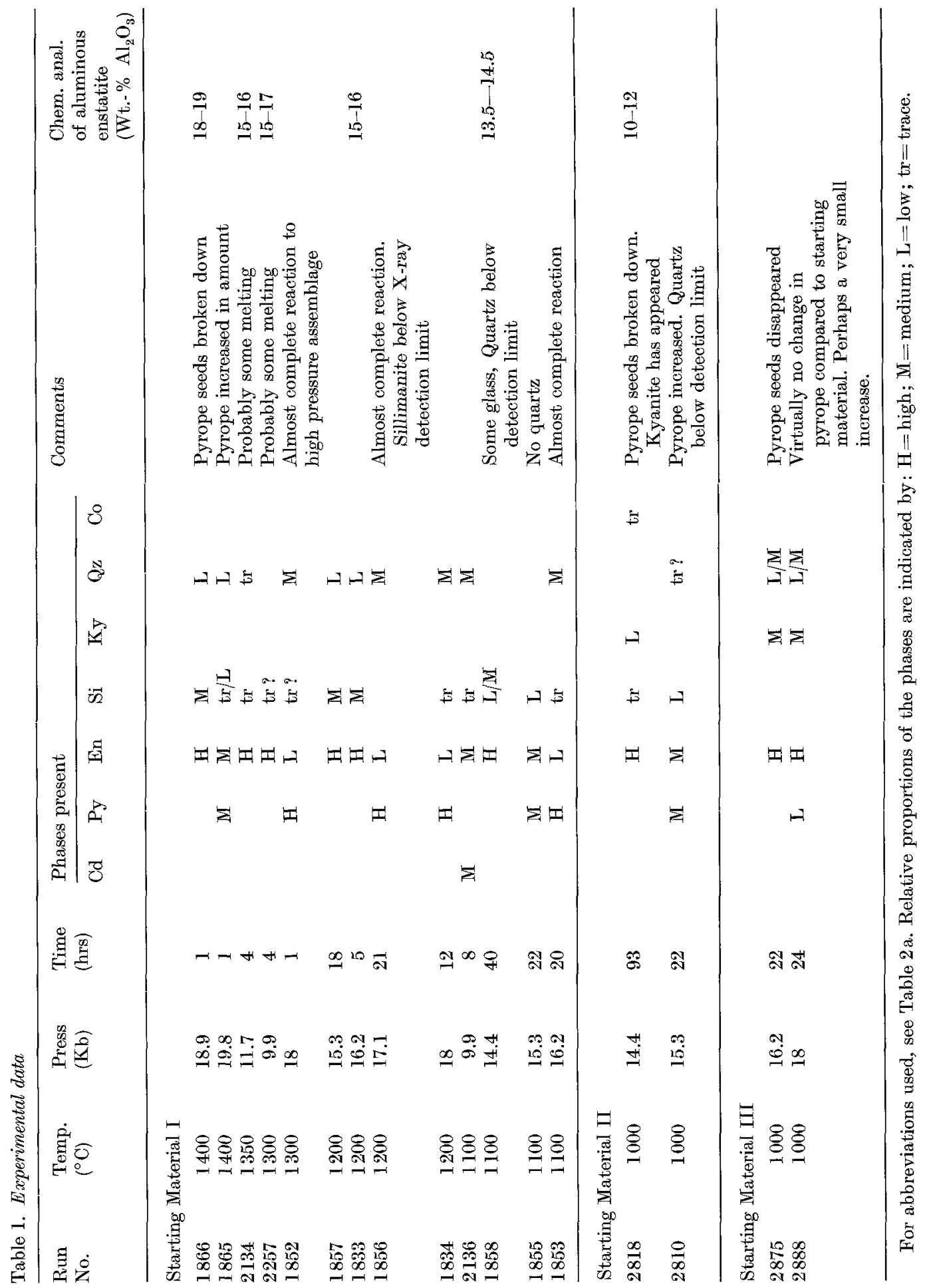




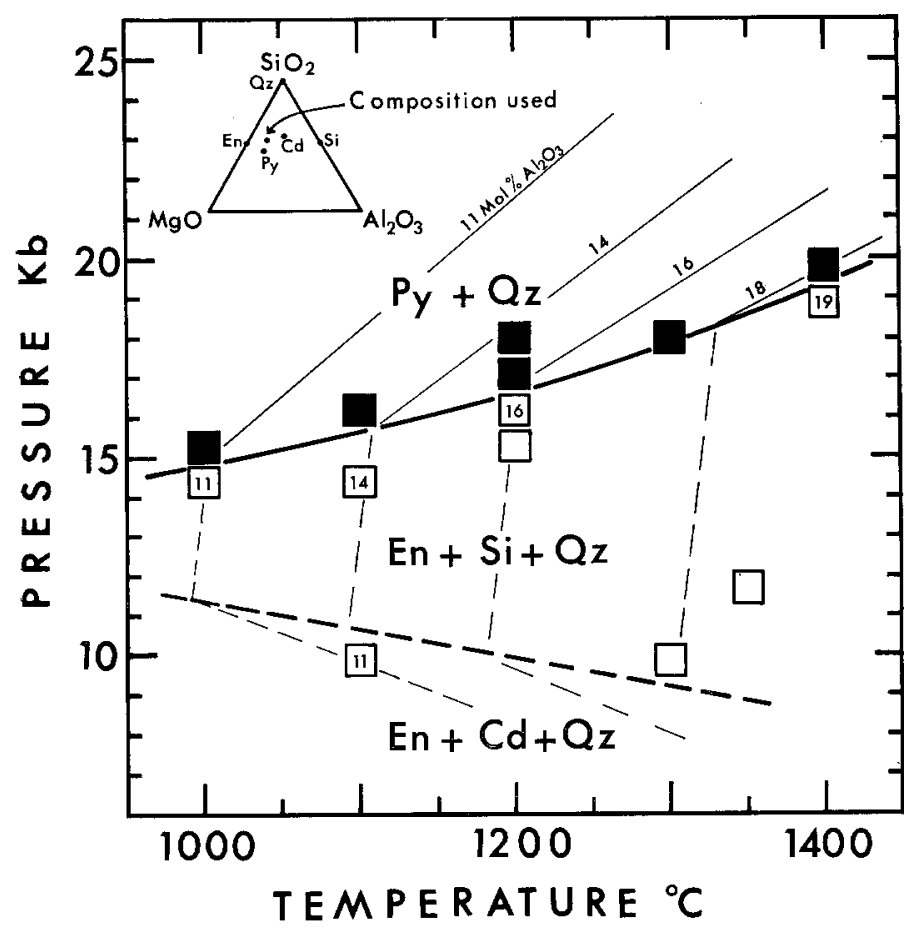

Fig. 1. Experimental $P-T$ diagram for pyrope + quartz composition. Numbers in squares indicate the measured Al-content ( $\mathrm{mol} \%$ ) of aluminous enstatite. Thin dashed lines show possible position of constant Al in enstatite contours. Lines for constant Al in the pyrope stability field have been extrapolated and corrected (pressure correction applied) from the data of Boyd and England (1964). Note that much of the length of both experimental phase boundaries in this diagram is metastable (compare Fig. 3 )

pyrope at $1000^{\circ} \mathrm{C}, 15.3 \mathrm{~kb}$ at the expense of enstatite and sillimanite is a metastable process and that the assemblage aluminous enstatite and kyanite is stable under these conditions. This has been verified experimentally. At $1000^{\circ} \mathrm{C}, 16.2 \mathrm{~kb}$ pyrope disappeared from a seeded run and aluminous enstatite, kyanite and quartz are stable. At $18 \mathrm{~kb}$ the pyrope seeds have persisted, but an increase of pyrope could not be established with certainty.

Experimental work by Schreyer and Seifert (1969a), Chatterjee and Schreyer (1970) and Hensen and Green (1970) leads us to believe that part of the presently determined phase boundary between pyrope + quartz and aluminous enstatite + sillimanite + quartz (Fig. 1) is metastable with respect to the reaction

pyrope $\rightleftharpoons$ aluminous enstatite + sapphirine + quartz.

This is due to the intersection of this reaction with the reaction

aluminous enstatite + sillimanite $\rightleftharpoons$ sapphirine + quartz .

The metastable persistence of aluminous enstatite and sillimanite is apparently due to the failure of sapphirine to nucleate spontaneously in short duration runs in this part of the system. 
The experimental data marking the breakdown of pyrope + quartz fit a slightly curved boundary. This is consistent with the observation that the alumina content of enstatite is strongly temperature dependent (Boyd and England, 1964). The stability field of pyrope is probably progressively reduced with temperature due to this effect. The amount of curvature in the slope however is not sufficiently determined by the present data, nor can it be predicted on the basis of presently available thermo-chemical information.

The reversed boundary for the breakdown of pyrope under its own composition as determined by Boyd and England (1959) lies at the high pressure side of the presently determined curve for pyrope + quartz from 1100 to $1400^{\circ} \mathrm{C}$. It now seems likely that both curves have been determined largely in their metastable extensions on the high temperature side of their intersection point at $1125 \pm 25^{\circ} \mathrm{C}$. Therefore, this situation is theoretically expected.

In comparing Boyd and England's data on pyrope breakdown and the present data on pyrope + quartz, it is necessary to carefully evaluate any difference in experimental technique. Boyd and England used talc (American variety) while the present experiments use talc (Australian variety) and boron-nitride as pressure media.

A detailed study of pressure media by one of the authors (Essene, in preparation) suggests that a relative correction to the data of Boyd and England should be made to compare them with our data which have a $-10 \%$ pressure correction. Because at $1400{ }^{\circ} \mathrm{C}$ talc by itself has a lower strength than talc + boron-nitride, only a $-6 \%$ correction has to be applied to their data at this temperature. At $1100^{\circ}$ a $-13 \%$ correction (which is $3 \%$ larger than our correction) needs to be made. We can use these corrected values and compare them with the present data. In this manner, an invariant point at the intersection of the two phase boundaries can be estimated that is consistent with the available experimental data (Fig. 3).

The presence of a quenched liquid in experiments by Schreyer and Seifert $(1969 \mathrm{~b})$ at $975{ }^{\circ} \mathrm{C}$ and lower temperatures makes it difficult to compare them with the other subsolidus data.

The occurrence of a large stability field for the assemblage pyrope-quartz as evidenced by the present data is in disagreement with the conclusion of Schreyer and Seifert (1969 b) that pyrope is incompatible with free silica over the pressuretemperature range in which quartz is the stable polymorph.

The stippled boundary between the low and intermediate pressure assemblages in Fig. 1 represents the reaction

cordierite $\rightleftharpoons$ aluminous enstatite + sillimanite + quartz.

This transition is probably also largely metastable at high temperatures with respect to

$$
\text { cordierite } \rightleftharpoons \text { sapphirine }+ \text { quartz }
$$

which has to lie on its low pressure side. Both these breakdown reactions have been found experimentally at 1100 and $1200^{\circ} \mathrm{C}$, respectively by Schreyer and Yoder (1960). 


\section{Chemical Analysis of Aluminous Pyroxenes}

An electron probe X-ray microanalyser (A.R.L. Model EMX) was used for the analysis of aluminous pyroxenes. Setting: Accelerating voltage $12 \mathrm{kV}$, emission current $90 \mathrm{~mA}$. sample current 0.04 microamps, counting time 20 seconds. $\mathrm{Mg}$, $\mathrm{Si}$, and Al were analysed simultaneously. Synthetic pyrope was used as a standard. No corrections were made to the data (other than for drift, background and dead time). A large number of analyses was made on each sample. Only those analyses which recalculated to nearly stoichiometric pyroxenes were selected. In each run, a range of alumina content was found, indicating that the charge did not completely equilibrate. A strong concentration of values within a range of one or two weight percent was found in all samples. These are the values listed in Table 1 . The higher values in the range measured for each temperature are consistent within experimental error with the extrapolated and corrected data of Boyd and England (1964) on aluminous enstatite in equilibrium with pyrope as shown in Fig. 1. The $\mathrm{Al}_{2} \mathrm{O}_{3}$-content of pyroxene in runs 2134 and 2257 is abnormally low. In these two runs, sillimanite is absent so that a different phase assemblage is present and the Al-content of enstatite is no longer fixed by the same partition relationships. Because the composition studied lies on the pyropequartz join (Fig. 1) aluminous enstatite does not occur in the high pressure assemblage. It coexists with sillimanite and quartz and with cordierite and quartz at intermediate and low pressures. The relevant exchange reactions are given below. They have been written such as to produce one mole of aluminous enstatite in each case:

\begin{tabular}{|c|c|}
\hline & $\Delta V_{n}=14.8^{\mathrm{a}}$ \\
\hline $\begin{array}{l}(1-\mathrm{n}) \mathrm{MgSiO}_{3}+\mathrm{n} \mathrm{Mg} \mathrm{Mg}_{3} \mathrm{Al}_{2} \mathrm{Si}_{3} \mathrm{O}_{12} \rightleftharpoons(1-\mathrm{n}) \mathrm{MgSiO}_{3} \cdot \mathrm{n} \mathrm{Al}_{2} \mathrm{O}_{3} \\
\text { enstatite }+ \text { pyrope } \\
\text { aluminous enstatite }\end{array}$ & $+1.27=$ \\
\hline $\begin{array}{l}\text { (I-n) } \mathrm{MgSiO}_{3}+\mathrm{n} \mathrm{Al}_{2} \mathrm{SiO}_{5} \rightleftharpoons(\mathrm{I}-\mathrm{n}) \mathrm{MgSiO}_{3} \cdot \mathrm{n} \mathrm{Al}_{2} \mathrm{O}_{3}+\mathrm{n} \mathrm{\textrm {SiO } _ { 2 }} \\
\text { enstatite }+ \text { sillimanite }\end{array}$ & $+0.2 \pm 0.1$ \\
\hline $\begin{array}{cc}(1-2 \mathrm{n}) \mathrm{MgSiO}_{3}+1 / 2 & \mathrm{n} \mathrm{Mg}_{2} \mathrm{Al}_{4} \mathrm{Si}_{5} \mathrm{O}_{18} \rightleftharpoons(\mathrm{l}-\mathrm{n}) \mathrm{MgSiO}_{3} \cdot \mathrm{n} \mathrm{Al}_{2} \mathrm{O}_{3}+{ }^{3} / 2 \mathrm{n} \mathrm{SiO} \mathrm{O}_{2} \\
\text { enstatite }+ \text { cordierite } & \text { aluminous enstatite }+ \text { quartz }\end{array}$ & $-3.27 \pm 0.08$ \\
\hline \multicolumn{2}{|c|}{$\begin{array}{l}n=\text { mole fraction of } \mathrm{Al}_{2} \mathrm{O}_{3} \text { in enstatite } \mathrm{b} \text {. The aluminous enstatite can also be written as } \\
\left(\mathrm{Mg}_{1-\mathrm{n}} \mathrm{Al}_{\mathrm{n}}\right)\left(\mathrm{Si}_{\mathrm{1}-\mathrm{n}} \mathrm{Al}_{\mathrm{n}}\right) \mathrm{O}_{3} \text {. } \\
\text { a Volume data for aluminous enstatite from Skinner and Boyd (1964): Volume for } \mathrm{n}=14.81 \\
\left.\text { (=15 weight \% } \mathrm{Al}_{2} \mathrm{O}_{3}\right)=30.87 \mathrm{~cm}^{3} \text {. The error of } \pm 0.05 \mathrm{~cm}^{3} \text { has been estimated. } \\
\text { b The expression of the reactions proposed here is different from that employed by Ring- } \\
\text { wood et al. (1964) and MeGregor and Ringwood (1964). Their use of molecular percent instead } \\
\text { of mole per cent or mole fraction is confusing. }\end{array}$} \\
\hline
\end{tabular}

For the undersaturated part of the system two more reactions of the same type involving corundum and spinel-forsterite can be written.

All these equilibria are divariant and have in common that they involve only one phase of variable composition (i.e. aluminous enstatite). The composition of 
the enstatite fixes pressure and temperature on a "univariant" compositional contour (Fig. 1). In the case of divariant reactions involving both aluminous enstatite and aluminous sapphirine, we have two phases of variable composition, and thus both pressure and temperature are uniquely determined by the compositions of the coexisting sapphirine and enstatite. On a $P-T$ diagram, this is represented by the intersection if two compositional contours. Examples of such equilibria include: En-Sa-Qz, En-Sa-Si and En-Sa-Cd.

\section{Topological Analysis}

In order to evaluate the implications of the experimental data for the $P-T$ diagram of the system $\mathrm{MgO}-\mathrm{Al}_{2} \mathrm{O}_{3}-\mathrm{SiO}_{2}$, it is useful to consider theoretically the possible geometry of phase relationships in this system.

The topology of the six phase system cordierite-enstatite-pyrope-sapphirine ${ }^{1}$ sillimanite-quartz is represented in Fig. 2. The $P-T$ diagram has been constructed by Schreinemaker's method with the additional restrictions imposed by the knowledge of the following information:

1. the volume changes of the univariant reactions (Table 2).

2. the negative slopes for the cordierite breakdown curves and the positive slope for the breakdown of pyrope.

The knowledge of the slopes of two univariant curves at an invariant point and the molar volumes of the phases participating in the reactions, allows one to calculate the slopes of the other univariant curves passing through this invariant point. Because of errors resulting from uncertainties in the experimentally determined slopes and the volume data these calculations cannot as yet lead to accurate results.

In Fig. 2 the relative slopes of the univariant boundaries are only qualitatively determined. From Fig. 2 it can be seen that two of the six invariant points in the system have to be metastable. The other points (Py), (Cd), (Sa) and (Qz) theoretically could be stable. The stable status of the latter two points is brought into question by considering the introduction of two new phases, e.g. kyanite and corundum.

As indicated previously, the kyanite-sillimanite phase boundary intersects the curves $(\mathrm{Cd}, \mathrm{Sa})^{2}$ and $(\mathrm{Cd}, \mathrm{Qz}$ ). This will have the effect of moving the invariant points (Sa) and (Qz) to lower temperatures because of the necessary inflections of all curves intersected by the $\mathrm{Ky}$-Si inversion. The new points (Sa) and ( $\mathrm{Qz}$ ) would then have kyanite instead of sillimanite as the stable alluminosilicate (see Fig. 2 and 3; also, next section). The experimental evidence indicates that (Sa) is metastable as well, due to the fact that curves for the breakdown of cordierite and pyrope + quartz diverge towards low temperature (Fig. 3). This precludes the stable coexistence of pyrope and cordierite in the presence of quartz.

According to Schreyer and Seifert (1969a) reactions involving corundum occur in the under-saturated part of the system. If their interpretation that these

1 For simplicity, the variable alumina content of enstatite and sapphirine has been neglected. The role of kyanite and other phases such as corundum, spinel and olivine, which become important in undersaturated compositions, has been disregarded.

$2(X, Z)$ indicates reaction from which phases $X$ and $Z$ are both absent. This reaction connects invariant points $(X)$ and $(Z)$ (see Table 2 ). 
Table 2a. Chemical and thermodynamic information for part of the system $\mathrm{MgO}-\mathrm{Al}_{2} \mathrm{O}_{3}-\mathrm{SiO}_{2}$

\begin{tabular}{llllll}
\hline Phase & $\begin{array}{l}\text { Abbre- } \\
\text { viation }\end{array}$ & $\begin{array}{l}\text { Chemical } \\
\text { formula }\end{array}$ & $\begin{array}{l}\text { Molar } \\
\text { volume } \\
\left(\mathrm{cm}^{3}\right)\end{array}$ & $\begin{array}{l}\text { Uncer- } \\
\text { tainty }\end{array}$ & $\begin{array}{l}\mathrm{T} \\
\left({ }^{\circ} \mathrm{C}\right)\end{array}$ \\
\hline Cordierite & $\mathrm{Cd}$ & $\mathrm{Mg}_{2} \mathrm{Al}_{4} \mathrm{Si}_{5} \mathrm{O}_{18}$ & 233.22 & \pm 0.13 & 25 \\
Enstatite & $\mathrm{En}$ & $\mathrm{MgSiO}_{3}$ & 31.44 & \pm 0.05 & $\mathrm{r}$ \\
Sapphirine & $\mathrm{Sa}$ & $\mathrm{Mg}_{2} \mathrm{Al}_{4} \mathrm{SiO}_{10}$ & 99.5 & \pm 0.73 & $\mathrm{r}$ \\
Pyrope & $\mathrm{Py}$ & $\mathrm{Mg}_{3} \mathrm{Al}_{2} \mathrm{Si}_{3} \mathrm{O}_{12}$ & 113.27 & \pm 0.03 & 25 \\
Sillimanite & $\mathrm{Si}$ & $\mathrm{Al}_{2} \mathrm{SiO}_{5}$ & 49.899 & \pm 0.004 & 25 \\
Kyanite & $\mathrm{Ky}$ & $\mathrm{Al}_{2} \mathrm{SiO}_{5}$ & 44.09 & \pm 0.07 & 25 \\
Quartz & $\mathrm{Qz}$ & $\mathrm{SiO}_{2}$ & 22.688 & \pm 0.001 & 25 \\
Corundum & $\mathrm{Co}$ & $\mathrm{Al}_{2} \mathrm{O}_{3}$ & 25.575 & \pm 0.007 & 25 \\
\hline
\end{tabular}

a Volume data from Robie et al. (1967).

Table $2 \mathrm{~b}$. Reactions in the system $\mathrm{MgO}-\mathrm{Al}_{2} \mathrm{O}_{3}-\mathrm{SiO}_{2}$ involving the six phases cordierte, enstatite, sapphirine, pyrope, sillimanite and quartz

\begin{tabular}{|c|c|c|c|}
\hline $\begin{array}{l}\text { Invariant } \\
\text { point }\end{array}$ & Reaction ${ }^{a}$ & $\Delta V\left(\mathrm{~cm}^{3}\right)^{\mathrm{b}}$ & $\begin{array}{l}\mathrm{dP} / \mathrm{d}^{\mathrm{T}} \mathrm{T}^{\mathrm{c}} \\
\left(\text { bars } /{ }^{\circ} \mathrm{C} \text { ) }\right.\end{array}$ \\
\hline $\mathrm{Sa}$ & $\begin{array}{l}\mathrm{Cd} \rightleftharpoons 2 \mathrm{En}+2 \mathrm{Si}+\mathrm{Qz}(\mathrm{Py}) \\
\mathrm{Cd}+4 \mathrm{En} \rightleftharpoons 2 \mathrm{Py}+3 \mathrm{Qz}(\mathrm{Si}) \\
3 \mathrm{Cd} \rightleftharpoons 2 \mathrm{Py}+4 \mathrm{Si}+5 \mathrm{Qz}(\mathrm{En}) \\
\mathrm{Py}+\mathrm{Cd} \rightleftharpoons 5 \mathrm{En}+3 \mathrm{Si}(\mathrm{Qz}) \\
3 \mathrm{En}+\mathrm{Si} \rightleftharpoons \mathrm{Py}+\mathrm{Qz}(\mathrm{Cd})\end{array}$ & $\begin{array}{r}-47.86 \pm 0.32 \\
-\quad 64.38 \pm 0.39 \\
-160.08 \pm 0.63 \\
-\quad 29.59 \pm 0.54 \\
-\quad 8.26 \pm 0.22\end{array}$ & $\begin{array}{l}-7.5 \\
+10\end{array}$ \\
\hline $\mathrm{Cd}$ & $\begin{array}{l}3 \mathrm{En}+\mathrm{Si} \rightleftharpoons \mathrm{Py}+\mathrm{Qz}(\mathrm{Sa}) \\
3 \mathrm{Sa}+7 \mathrm{Qz} \rightleftharpoons 2 \mathrm{Py}+4 \mathrm{Si}(\mathrm{En}) \\
4 \mathrm{En}+\mathrm{Sa}+\mathrm{Qz} \rightleftharpoons 2 \mathrm{Py}(\mathrm{Si}) \\
7 \mathrm{En}+\mathrm{Sa}+\mathrm{Si} \rightleftharpoons 3 \mathrm{Py}(\mathrm{Qz}) \\
\mathrm{Sa}+3 \mathrm{Qz} \rightleftharpoons 2 \mathrm{En}+2 \mathrm{Si}(\mathrm{Py})\end{array}$ & $\begin{array}{rr}-\quad 8.26 \pm 0.22 \\
-\quad 31.18 \pm 2.39 \\
-\quad 21.41 \pm 0.96 \\
-\quad 29.67 \pm 1.18 \\
-\quad 4.89 \pm 0.89\end{array}$ & $\begin{array}{l}+10 \\
(+33) \\
(+21) \\
+18 \\
(+59)\end{array}$ \\
\hline Py & $\begin{array}{l}\mathrm{Sa}+3 \mathrm{Qz} \rightleftharpoons 2 \mathrm{En}+2 \mathrm{Si}(\mathrm{Cd}) \\
\mathrm{Cd} \rightleftharpoons 2 \mathrm{En}+2 \mathrm{Si}+\mathrm{Qz}(\mathrm{Sa}) \\
\mathrm{Cd} \rightleftharpoons \mathrm{Sa}+4 \mathrm{Qz}(\mathrm{En}, \mathrm{Si}) \\
3 \mathrm{Cd}+\mathrm{Sa} \rightleftharpoons 8 \mathrm{En}+8 \mathrm{Si}(\mathrm{Qz})\end{array}$ & $\begin{array}{r}-\quad 4.89 \pm 0.89 \\
-\quad 47.86 \pm 0.32 \\
-\quad 42.97 \pm 0.83 \\
-148.45 \pm 1.84\end{array}$ & $\begin{array}{r}(+59) \\
-7.5 \\
(-15) \\
(-5)\end{array}$ \\
\hline \multirow[t]{2}{*}{$\mathrm{Qz}$} & $\begin{array}{l}3 \mathrm{Cd}+\mathrm{Sa} \rightleftharpoons 8 \mathrm{En}+8 \mathrm{Si}(\mathrm{Py}) \\
7 \mathrm{En}+\mathrm{Sa}+\mathrm{Si} \rightleftharpoons 3 \mathrm{Py}(\mathrm{Cd}) \\
16 \mathrm{En}+3 \mathrm{Sa}+\mathrm{Cd} \rightleftharpoons 8 \mathrm{Py}(\mathrm{Si}) \\
7 \mathrm{Cd}+5 \mathrm{Sa} \rightleftharpoons 8 \mathrm{Py}+16 \mathrm{Si}(\mathrm{En}) \\
\mathrm{Py}+\mathrm{Cd} \rightleftharpoons 5 \mathrm{En}+3 \mathrm{Si}(\mathrm{Sa})\end{array}$ & $\begin{array}{l}-148.45 \pm 1.84 \\
-29.67 \pm 1.18 \\
-128.60 \pm 3.27 \\
-425.48 \pm 5.35 \\
-29.59 \pm 0.54\end{array}$ & \\
\hline & $\mathrm{Si} \rightleftharpoons \mathrm{Ky}$ & $-\quad 5.81 \pm 0.11$ & +23.23 \\
\hline
\end{tabular}

a The sillimanite in the reactions can be replaced by kyanite. For a reaction involving $n$ moles of sillimanite the volume change of that reaction has to be adjusted by : $n(5.81 \pm 0.11)$.

$b$ The reactions have been written such that the right hand side always has the lower volume.

c Slopes estimated from experimental evidence. Figures in brackets are calculated from these using the volume data at room temperature given in the table. 


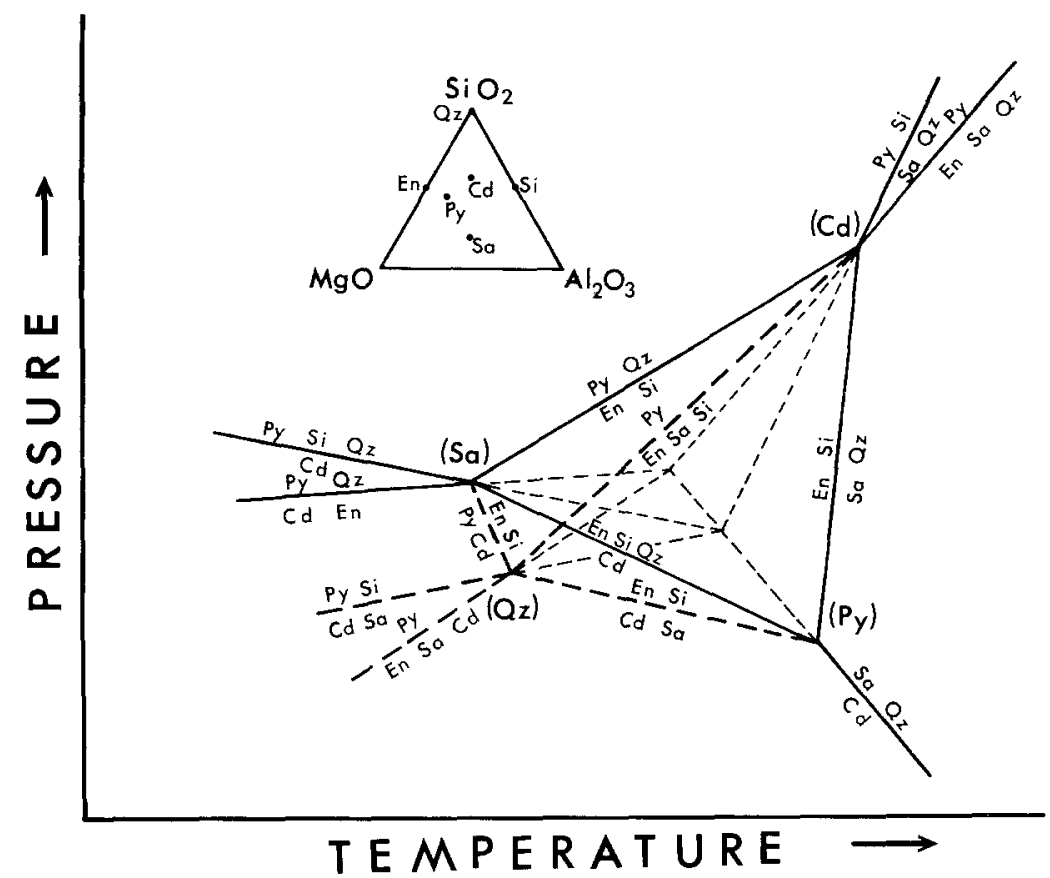

Fig. 2. Theoretical phase analysis of the system $\mathrm{MgO}-\mathrm{Al}_{2} \mathrm{O}_{3}-\mathrm{SiO}_{2}$ at high pressure and temperature

reactions intersect the stable part of the curve $(\mathrm{Py}, \mathrm{Qz})$ is correct, then the invariant point $(\mathrm{Qz})$ must be metastable. The reactions coming out of this point will be entirely or partly metastable. Pyrope will break down to enstatite and corundum below the intersection of the curve $(\mathrm{Cd}, \mathrm{Qz})$ and $\mathrm{Sa}+\mathrm{Si} \rightleftharpoons \mathrm{En}+\mathrm{Co}$ (Schreyer, 1968).

\section{Summary}

All available experimental evidence has been combined for the construction of a phase diagram for the silica-saturated part of the system $\mathrm{MgO}-\mathrm{Al}_{2} \mathrm{O}_{3}-\mathrm{SiO}_{2}$ (Fig. 3). The invariant point (Cd) has been obtained by a combination of the breakdown curves for pyrope + quartz (this work) and for pyrope (Boyd and England, 1964). The slope of the former reaction has been estimated at +10 bars $/{ }^{\circ} \mathrm{C}$. The maximum slope allowed by the experimental data (after pressure correction) of +18 bars $/{ }^{\circ} \mathrm{C}$ has been chosen for the latter. The invariant point occurs at $1125 \pm 25^{\circ} \mathrm{C}$ and $16 \pm 1 \mathrm{~kb}$. The uncertainty limits are perhaps somewhat optimistic. However, the intersection is unlikely to occur at higher temperature because this would require an even larger relative pressure correction for Boyd and England's data. At lower temperature, the position of the invariant point is limited by the calculated positive slope for the reactions between enstatitesillimanite and sapphirine-quartz. The position of this reaction is restricted by an approximate knowledge of the invariant point (Py) (Chatterjee and Schreyer, 1969). 


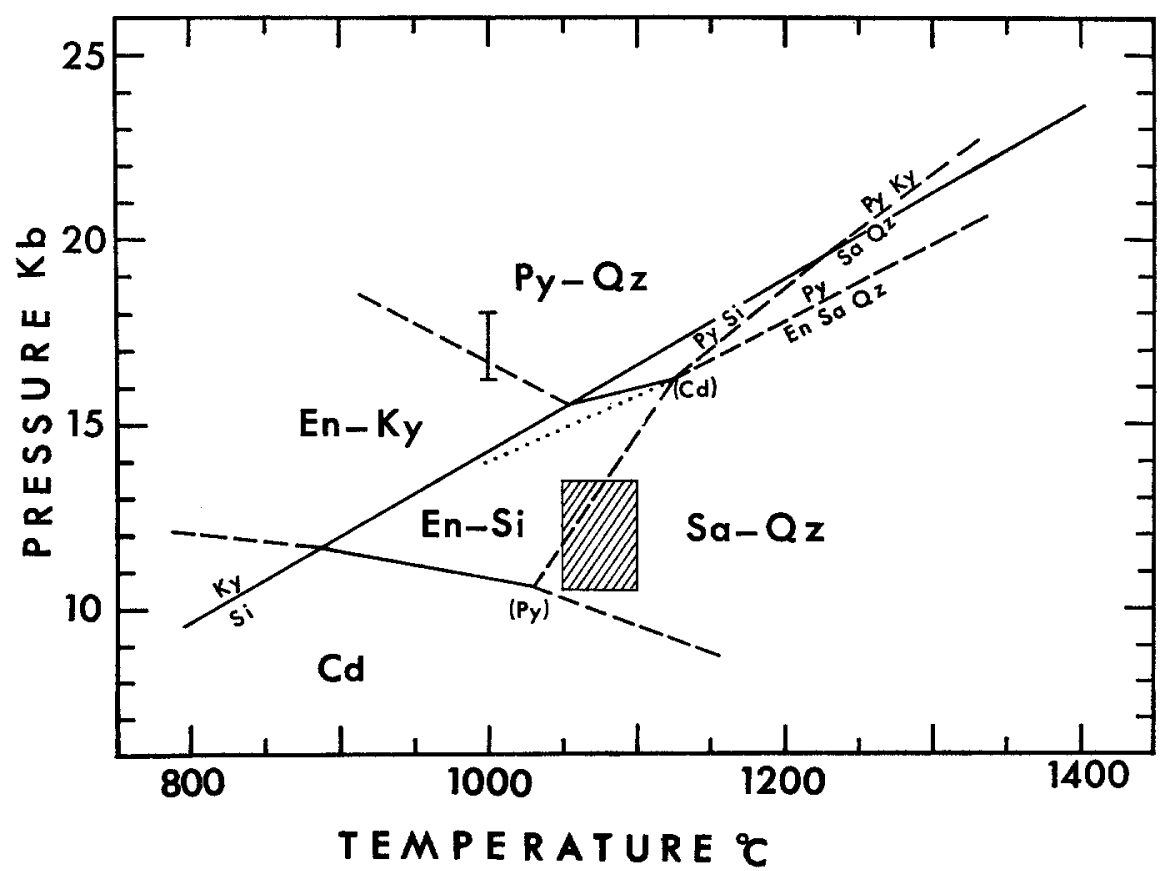

Fig. 3. Model phase diagram for the system $\mathrm{MgO}-\mathrm{Al}_{2} \mathrm{O}_{3}-\mathrm{SiO}_{2}$. This diagram is a "best fit" being consistent with all experimental evidence. Solid lines: Ky-Si phase boundary after Richardson et al. (1968) (pressure correction applied). The other two lines are segments of the phase boundaries from Fig. 1. Dotted line: corrected and extrapolated phase boundary for the breakdown of pyrope to enstatite, sapphirine and sillimanite (Boyd and England, 1959). Dashed lines: calculated phase boundaries. The I bar represents the experimental reversal of $\mathrm{En}+\mathrm{Ky} \rightleftharpoons \mathrm{Py}+\mathrm{Qz}$ as discussed in the text. Shaded rectangle: estimated position of the invariant point (Py) by Chatterjee and Schreyer (1969)

The position of the boundary for the breakdown of cordierite has been estimated from the present data and data on the $B_{100}$ composition (Hensen, 1970). The slope of -7.5 bars $/{ }^{\circ} \mathrm{C}$ is consistent with available evidence. The negative slopes for the breakdown curves of cordierite require this phase to have a lower entropy than its less voluminous breakdown products. The high temperature entropies for the phases cordierite, enstatite, sillimanite and quartz are known (Robie and Waldbaum, 1968). On the basis of this information, the entropy change for the reaction involving these phases should be negative for the temperature range of interest. It is possible that ordering in the cordierite and mixing of $\mathrm{Al}_{2} \mathrm{O}_{3}$ in the enstatite and sapphirine cause the change of sign required by the experimental evidence.

The kyanite-sillimanite boundary has been constructed such as to pass below $14.4 \mathrm{~kb}$ at $1000^{\circ} \mathrm{C}$. If the triple point of Richardson et al. (1969) at $622^{\circ} \mathrm{C}$, $5.5 \mathrm{~kb}$ is taken as being correct, a slope of $23.2 \mathrm{bars} /{ }^{\circ} \mathrm{C}$ is consistent with the present data. This slope happens to require a $-6 \%$ correction for the "piston in" data at $1500^{\circ} \mathrm{C}$ ef. Richardson et al. (1968). This is the same correction which has been applied to Boyd and England's pyrope data at $1400^{\circ} \mathrm{C}$.

6 Contr. Mineral. and Petrol., Vol. 30 
The calculated (negative) slope for the reaction enstatite + kyanite $\rightleftharpoons$ pyrope + quartz is $-21 \mathrm{bars} /{ }^{\circ} \mathrm{C}$. The other slopes for reactions of interest have been calculated and are given in Table 2 and shown in Fig. 3. It has to be emphasized that although the phase diagram is consistent with experimental evidence to date, there still remains considerable uncertainty as to the exact location of the invariant points and the slopes of the phase boundaries.

\section{Influence of Other Components}

The addition of another component $(\mathrm{FeO})$ to the system will increase its variance by one. Four-, five- and six-phases coexist in di-, uni- and invariant equilibrium, respectively. This means that the invariant points in the simple system become univariant lines and the univariant curves change into divariant bands.

Whether the addition of $\mathrm{FeO}$ will enlarge the stability field of a particular phase will depend on the distribution of Fe and $\mathrm{Mg}$ between the phase in question and the coexisting ferromagnesian phase(s).

From natural occurrences, the following sequence is generally found:

$(\mathrm{Mg} / \mathrm{Fe})_{\text {cordierite }}>(\mathrm{Mg} / \mathrm{Fe})_{\text {sapphirine }}>(\mathrm{Mg} / \mathrm{Fe})_{\text {hypersthene }}>(\mathrm{Mg} / \mathrm{Fe})_{\text {garnet }} \quad($ Barker, 1964; Hensen, unpublished data).

This means that with increasing $\mathrm{FeO}$ content the stability field of garnet is increased with respect to the three other phases, that of hypersthene with respect to sapphirine and cordierite and that of sapphirine with respect to cordierite. A more detailed discussion of these problems is given in Hensen and Green (1970) and Hensen (1970).

\section{Application}

Direct applications of simple system data to natural rocks are necessarily restricted because rocks sufficiently close in composition to the system $\mathrm{MgO}-\mathrm{Al}_{2} \mathrm{O}_{3}-\mathrm{SiO}_{2}$ are very rare.

Chinner and Sweatman (1968) have described a rock the composition of which is very close to that of pure magnesian cordierite. They concluded that this rock, now mainly consisting of enstatite and sillimanite (with additional cordierite, quartz and corundum) has previously contained the assemblage enstatite-kyanitequartz. Their estimate for the formation of this assemblage above $10 \mathrm{~kb}$ is consistent with Fig. 3.

As indicated above, the presence of $\mathrm{FeO}$ (in most natural rocks) considerably changes the phase relationships in this system. An example is the incompatibility of pyrope and cordierite in the presence of quartz. Both from experimental evidence (Hensen and Green, 1969, 1970; Hirschberg and Winkler, 1968) and from natural rocks it is well established that cordierite, almandine-pyrope garnet and quartz can coexist over a wide range of pressures, temperatures and chemical compositions. This also shows that the univariant equilibria which are metastable in the end member system, can become stable (divariant) by the addition of another component (in this case $\mathrm{FeO}$ ).

Acknowledgements. The authors want to thank Dr. D. H. Green for his interest in the work and for critical reading of the manuseript. 


\section{References}

Boyd, F. R., England, J. L.: Pyrope. Carnegie Inst. Washington Year Book 58, 83-87 (1959). - - The system enstatite-pyrope. Carnegie Inst. Washington Year Book 63, 157-161 (1964). Chatterjee, N. D., Schreyer, W.: Stabilitätsbeziehungen der paragenese sapphirin und quartz. Deutsche Min. Ges. Referate der Vorträge auf der 47. Jahrestagg, Bern. 7-8, 1969.

Chinner, G. A., Sweatman, T. R.: A former association of enstatite and kyanite. Mineral. Mag. 36, 1052-1060 (1968).

Green, D. H., Ringwood, A. E.: An experimental investigation of the gabbro to eclogite transformation and its petrological applications. Geochim. Cosmochim. Acta 31, 767-833 (1967).

Hensen, B. J.: Experimental study of the stability of cordierite and garnet in pelitic compositions at high pressures and temperatures. Ph.D. dissertation, Australian National University. 1970

- Green, D. H.: Experimental data on the stability of garnet and cordierite in high-grade metamorphic rocks. Spec. Publs geol. Soc. Aust. 2, 345-347 (1969).

- Experimental data on coexisting cordierite and garnet under high grade metamorphic conditions. Phys. Earth Planet. Int. 8, 431-440 (1970).

MacGregor, I. D., Ringwood, A. E.: The natural system enstatite-pyrope. Carnegie Inst. Washington Year Book 63, 161-165 (1964).

Richardson, S. W., Bell, P. M., Gilbert, M. C.: Kyanite-sillimanite equilibrium between $700^{\circ}$ and $1500{ }^{\circ} \mathrm{C}$. Am. J. Science $266,513-541$ (1968).

- Gilbert, M. C., Bell, P. M.: Experimental determination of kyanite-andalusite and andalusite-sillimanite equilibria; the aluminium silicate triple point. Am. J. Science 267, 259-272 (1969).

Ringwood, A. E., MacGregor, I. D., Boyd, F. R.: Petrological constitution of the upper mantle. Carnegie Inst. Washington Year Book 63, 147-152 (1964).

Robie, R. A., Bethke, P. M., Beardsley, K. M.: Selected X-ray crystallographic data molar volumes, and densities of minerals and related substances. Geol. Survey Bull. 1248 (1967).

- Waldbaum, D. R.: Thermodynamic properties of minerals and related substances at $298.15^{\circ} \mathrm{K}\left(25.0^{\circ} \mathrm{C}\right)$ and one atmosphere $(1.013$ Bars $)$ pressure and at higher temperatures. Geol. Survey Bull. 1259 (1969).

Schreyer, W.: A reconnaissance study of the system $\mathrm{MgO}-\mathrm{Al}_{2} \mathrm{O}_{3}-\mathrm{SiO}_{2}-\mathrm{H}_{2} \mathrm{O}$ at pressures between 10 and $25 \mathrm{~Kb}$. Carnegie Inst. Year Book 67, 380-392 (1968).

- Seifert, F.: Compatibility relations of the aluminium silicates in the systems $\mathrm{MgO}-\mathrm{Al}_{2} \mathrm{O}_{3}$ $\mathrm{SiO}_{2}-\mathrm{H}_{2} \mathrm{O}$ and $\mathrm{K}_{2} \mathrm{O}-\mathrm{MgO}-\mathrm{Al}_{2} \mathrm{O}_{3}-\mathrm{SiO}_{2}-\mathrm{H}_{2} \mathrm{O}$ at high pressures. Am. J. Science 267, 371-388 (1969a).

- - High pressure phases in the system $\mathrm{MgO}-\mathrm{Al}_{2} \mathrm{O}_{3}-\mathrm{SiO}_{2}-\mathrm{H}_{2} \mathrm{O}$. Am. J. Science $267 \mathrm{~A}$, $407-443(1969 \mathrm{~b})$.

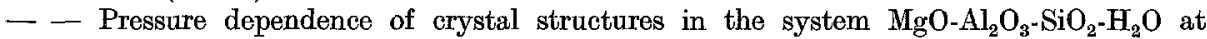
pressures up to 30 kilobars. Phys. Earth Planet. Int. 3, 422-430 (1970).

- Yoder, H. S., Jr.: Instability of anhydrous Mg-cordierite at high pressures. Carnegie Inst. Washington Year Book 59, 90-91 (1960).

Dr. B. J. Hensen

Department of Geophysics and Geochemistry

P.O. Box 4

Canberra, A.C.T. 2600, Australia 